Удк 338.1

DOI: https://doi.org/10.32843/infrastruct49-18

\section{Бондаренко С.М.}

к.е.н., доцент,

доцент кафедри менеджменту

та публічного адміністрування

Київський національний університет

технологій та дизайну

Гладуш А.O.

магістр

Київський національний університет

технологій та дизайну

\section{Bondarenko Svitlana}

Kyiv National University

of Technologies and Design

Hladush Andrii

Kyiv National University

of Technologies and Design
Впродовж останніх років спостерігається тенденція зростання конкуренції між приватними, державними та комунальними медичними закладами за прихильність пацієнтів. Для перемоги у конкурентній боротьбі медичні заклади повинні бути конкурентоспроможними. Важливого значення набуває оцінка досягнутого рівня конкурентоспроможності закладів у сфрері охорони здоров'я. Оцінено конкурентоспроможність медичних закладів з використанням методики профр. Г.П. Іспіряна на основі даних, отриманих експертним методом. Експерти вибрали найвагоміші показники та оцінювали ї для чотирьох приватних клінік за 5-бальною шкалою. Побудовано багатокутник конкурентоспроможності, який містить достатню інформацію про сильні і слабкі сторони медичних закладів. Медичні заклади було проранжовано і визначено середній ранг та показник конкурентоспроможності, на основі яких визначено лідерів та аутсайдерів серед медичних закладів. Результати оцінки конкурентоспроможності можуть знайти використання у медичному закладі для формування прогнозів розвитку, розроблення стратегій досягнення конкурентних переваг, оптимізації асортименту медичних послуг тощо.

Ключові слова: конкуренція, конкурентоспроможність, заклад охорони здоров'я, оцінка, показник конкурентоспроможності.

На протяжении последних лет наблюдается тенденция роста конкуренции между частными, государственными и коммунальными медицинскими учреждениями за приверженность пациентов. Для победы в конкурентной борьбе медицинские учреждения должны быть конкурентоспособными. Важное значение приобретает оценка достигнутого уровня конкурентоспособности учреждений в сфере здравоохранения. Оченена конкурентоспособность медицинских учреждений с использованием методики проср. П. Испиряна на основе данных, полученных экспертным методом. Эксперты выбрали наиболее значимые показатели и оценивали их для четырех частных клиник по 5-балльной шкале. Построен многоугольник конкурентоспособности, который содержит достаточную инсрормацию о сильных и слабых сторонах медицинских учреждений. Медицинские учреждения были проранжированы и определен средний ранг и показатель конкурентоспособности, на основе которых определены лидеры и аутсайдеры среди медицинских учреждений. Результаты оценки конкурентоспособности могут найти применение в медицинском учреждении для формирования прогнозов развития, разработки стратегий достижения конкурентных преимуществ, оптимизации ассортимента медицинских услуг и др.

Ключевые слова: конкуренция, конкурентоспособность, учреждение здравоохранения, оценка, показатель конкурентоспособности.

In recent years, there has been a growing trend of competition between private, public and utilities medical institutions for patient adherence. Consumers have the opportunity to choose a medical institution, which means that there is competition in the market of medical care. To win the competition, medical facilities must be competitive. It is important to assess the level of competitiveness achieved by healthcare facilities. The competitiveness of a medical institution can be defined as a complex comparative characteristic that represents the degree of superiority of a set of evaluation indicators of its activities that determine the success of the enterprise in a particular market over time, over a set of competitors. The competitiveness of medical institutions was assessed by a quantitative method using the method of prof. Ispiryana G.P. based on data obtained by the expert method. The experts selected the most important indicators and evaluated them for four private clinics on a 5-point scale. These are such indicators as the quality of medical services, level of professionalism of doctors, building relationships with a patient, price of medical services, organization of the medical institution, cleanliness and tidiness of the premises, location. The consistency of experts' opinions was checked. The concordance coefficient was calculated, which confirmed the consistency of experts' opinions. A competitiveness polygon has been built, which contains sufficient information about the strengths and weaknesses of medical institutions. In competition, the first task of the organization is to survive, not to perish, to function as long as possible. To do this, it must first move away as far as possible from the area where threats to its existence are concentrated. This area is occupied by outsiders of competition, ie the task of the medical institution is to bypass as many competitors as possible, to leave them behind. Medical institutions were ranked and the average rank and competitiveness indicator were determined. Based on the competitiveness indicator, leaders and outsiders among medical institutions are identified. The results of competitiveness assessment can be used in a medical institution to form development forecasts, develop strategies to achieve competitive advantage, optimize the range of medical services, etc. Key words: competition, competitiveness, health care institution, assessment, competitiveness indicator.

Постановка проблеми. Питання конкуренції на ринку медичних послуг та конкурентоспроможності закладів охорони здоров'я до недавнього часу в Україні майже не розглядались, оскільки в умовах планової економіки серед державних закладів охорони здоров'я конкуренції не було. 3 появою приватних лікувальних закладів спостерігається тенденція зростання конкуренції між приватними, державними та комунальними медичними закладами за прихильність пацієнтів. У споживачів виникає можливість вибору медичного закладу, а це значить, що на ринку медичної допомоги виникає конкуренція. Для перемоги у конкурентній боротьбі медичні заклади повинні бути конкурентоспроможними. В цих умовах важливого значення набуває оцінка досягнутого рівня конкурентоспроможності закладів у ссрері охорони здоров'я.

Аналіз останніх досліджень і публікацій. Вагомий внесок у теорію конкуренції, конкурентних переваг та конкурентоспроможності зробили такі відомі вітчизняні та зарубіжні вчені, як Г.Л. Азоєв, О.С. Віханський, Г.Я. Гольдштейн, Г.П. Іспірян, Ф. Котлер, М.І. Круглов, В.Д. Нємцов, М. Портер, Р.А. Фатхутдінов, А.Ю. Юданов та інші. Питання конкурентних переваг медичних закладів розглянуто в працях $[7 ; 8 ; 10]$. Висвітленню питань 
конкурентоспроможності продукції та підприємств присвячено роботи $[1 ; 4 ; 5 ; 6 ; 9]$. На важливості питань якості як важливого чинника конкурентоспроможності наголошено в джерелах [2; 3].

Постановка завдання. Метою дослідження $€$ удосконалення методичних підходів до оцінки конкурентоспроможності медичних закладів у сорері охорони здоров'я. Виходячи 3 мети, було поставлено та вирішено такі завдання: обґрунтувати доцільність оцінки конкурентоспроможності медичних закладів; розглянути теоретичні основи оцінки конкурентоспроможності; запропонувати методичні підходи до оцінки конкурентоспроможності приватних клінік з використанням методики проф. Г.П. Іспіряна на основі даних, отриманих експертним методом.

Виклад основного матеріалу дослідження. Перехід на ринкові важелі та стимули господарювання створює якісно нові умови для обґрунтування національної концепції реформування системи охорони здоров'я відповідно до ст. 49 Конституції України на засадах багатоукладності та рівноправності державних, громадських та приватних фрорм власності медичних структур, які набувають організаційно-економічного статусу суб'єктів господарювання. Таким чином, медичні заклади поступово перетворюються на комерційні структури 3 необхідними атрибутами підприємницької діяльності [10].

Впровадження ринкових відносин у соціальну сореру $€$ складним завданням і потребує необхідності наукового обґрунтування особливостей управлінської діяльності на ринку медичної допомоги. Сучасні медичні заклади повинні бути конкурентоспроможними. Їхньою конкурентоспроможністю потрібно ефективно управляти, а для цього насамперед слід правильно оцінювати досягнутий рівень конкурентоспроможності.

Оцінка конкурентоспроможності медичного закладу необхідна для того, щоб оцінити його потенційні можливості в конкурентній боротьбі і розробити заходи підвищення конкурентоспроможності та забезпечення конку-рентних переваг.

Конкурентоспроможність медичного закладу може бути визначена як комплексна порівняльна характеристика, яка відображає ступінь переваги сукупності показників його діяльності, що визначають конкурентні переваги на певному ринку за певний проміжок часу щодо відповідної сукупності по-казників конкурентів.

Для оцінки конкурентоспроможності організації використовується ціла низка методів. За способом оцінки розрізняють якісні та кількісні методи оцінки конкурентоспроможності. Якісні методи оцінювання мають невисокий ступінь математичної фрормалізації, їм властива трудомісткість реалізації та дискретність оцінки. Вони не дають можливості використовувати оцінку конкурентоспроможності підприємства в процесі прийняття управлінських рішень. Кількісні методи дають змогу оцінювати реальні шанси суб'єкта господарювання у конкурентній боротьбі за привабливі стратегічні зони господарювання і приймати виважені тактичні та стратегічні управлінські рішення.

3 метою проведення оцінки конкурентоспроможності приватних медичних закладів з використанням кількісного методу, зокрема методики Г.П. Іспіряна, створено групу експертів. Для оцінки конкурентоспроможності медичного закладу та його конкурентів експертами були вибрані такі показники, як:

1. Якість медичних послуг - основна перевага медичного закладу. Сюди відноситься комплексний системний підхід до лікування, правильна постановка діагнозу, позитивний результат лікування, наявність необхідного обладнання, наявність медичних препаратів.

2. Рівень профресіоналізму лікарів - якість медичної освіти, наявність наукового ступеня, компетенції лікаря, стажування та підвищення кваліфрікації, досвід роботи.

3. Побудова відносин із пацієнтом - включає повагу, уважність до па-цієнта, оперативність надання медичних послуг, привітність, ввічливість, людяність персоналу.

4. Ціна медичних послуг - визначає «цінову прихильність» пацієнтів до медичного закладу, наявність програм лояльності.

5. Організація роботи лікувального закладу наявність сайту з необхідною інфрормацією, відсутність черг, режим роботи, наявність інорормації про медичний заклад у засобах масової інорормації.

6. Чистота та охайність приміщень - наявність ремонту в приміщеннях, чистота в кімнатах, дезінфрекція, кварцування приміщень.

7. Місце розташування - чинник, який істотно впливає на загальну відвідуваність медичного закладу, до якого має бути легко дістатися, має бути присутня приваблива та помітна вивіска.

Експерти оцінювали вибрані показники для чотирьох приватних клінік за 5-бальною шкалою. Проводилася перевірка узгодженості думок експертів. Розраховувався коефріцієнт конкордації, який підтвердив узгодженість думок експертів. Результати експертної оцінки конкурентоспроможності клінік зведено до таблиці 1.

Багатокутник конкурентоспроможності лікувальних закладів наведено на рис. 1. Для медичних закладів він містить достатню інфрормацію про власні сильні і слабкі сторони. Високу оцінку Клініка 1 отримала за двома важливими показниками, такими як рівень професіоналізму лікарів та ціна медичних послуг, а найнижчу - за організацію роботи лікувального закладу. Значними перевагами Клініки 1 перед деякими конкурентами $€$ якість надання медичних послуг. За цим важливим 
Підсумкова таблиця експертної оцінки конкурентоспроможності медичних закладів

\begin{tabular}{|l|c|c|c|c|}
\hline \multicolumn{1}{|c|}{ Показники } & Клініка 1 & Клініка 2 & Клініка 3 & Клініка 4 \\
\hline Якість медичних послуг & 4,8 & 4,9 & 4,7 & 4,5 \\
\hline Рівень просресіоналізму лікарів & 4,9 & 4,3 & 4,5 & 4,7 \\
\hline Побудова відносин із пацієнтом & 3,8 & 4,1 & 3,7 & 4,0 \\
\hline Ціна медичних послуг & 4,8 & 4,0 & 4,2 & 3,1 \\
\hline Організація роботи лікувального закладу & 3,8 & 5 & 4,9 & 4,7 \\
\hline Чистота та охайність приміщень & 4,5 & 4,8 & 4,7 & 4,6 \\
\hline Місце розташування & 3,5 & 4,8 & 2,5 & 4,0 \\
\hline
\end{tabular}

показником вона поступилася лише Клініці 2. За організацією роботи лікувального закладу Клініка 1 поступається всім конкурентам. Тому зусилля менеджерів цього медичного закладу повинні бути спрямовані на удосконалення організації роботи клініки. Перевагою Клініки 2 над всіма конкурентами є організація роботи лікувального закладу.

За методикою Г.П. Іспіряна експерти визначали відносне значення ознак у формуванні в пацієнта рішення про отримання медичних послуг у певному медичному закладі $\alpha_{i}$, де i - індекс ознаки.

Експерти ранжують медичні заклади послідовно за кожною ключовою ознакою окремо. Ранг $\rho_{\mathrm{ij}}=1$ присвоюють закладу ј, якщо за ознакою і він переважає всіх конкурентів. $\rho_{\mathrm{ij}}=5$ - якщо поступається всім конкурентам. Усі інші конкуренти отримують відповідні проміжні значення рангів $\rho_{\mathrm{ij}}=2,3,4$. До табл. 2 зведено отримані результати ранжування.

Для кожного медичного закладу визначають середній ранг за фрормулою:

$$
P_{c \rho}=\Sigma \alpha_{i} \rho_{i j}
$$

Конкурентоспроможність медичного закладу $\mathrm{KC}_{\text {вј }}$ розраховується за фрормулою:

$$
\mathrm{KC}_{\mathrm{Bj}}=\left(\rho_{\max }-\rho_{\mathrm{j}}\right) /\left(\rho_{\max }-1\right),
$$

де $\rho_{\max }$ - максимальний середній ранг медичного закладу-аутсайдера;

$\rho_{\mathrm{j}}$ - ранг медичного закладу, для якого визначають рівень конкурентоспроможності.

у конкурентній боротьбі найперше завдання організації - вижити, не загинути, проіснувати якнайдовше [5]. Для цього їй потрібно насамперед якнайдалі відійти від зони, де зосереджені загрози для іiї існування. Ця зона зайнята аутсайдерами конкурентної боротьби, тобто завдання медичного закладу - обійти якомога більше конкурентів, залишити їх позад себе. Знаменник у фрормулі (2) саме й показує максимальне число конкурентів, яких можна обійти. А чисельник показує, яка кількість конкурентів, що залишилась фрактично позаду фрірми.

Якщо організація перша серед конкурентів, то $\mathrm{KC}_{\mathrm{Bj}}=1$, а якщо остан-ня, то $\mathrm{KC}_{\text {вј }}=0$. Показник $\mathrm{KC}_{\mathrm{вj}}$ може мати значення у межах $0 \leq \mathrm{KC}_{\mathrm{вj}} \leq 1$.

Виходячи із проведеної оцінки конкурентоспроможності, лідером є Клініка 2, аутсайдером - Клініка 4.

Результати оцінки конкурентоспроможності можуть знайти використання в медичному закладі для фрормування прогнозів розвитку лікувальних закладів, розроблення стратегій досягнення

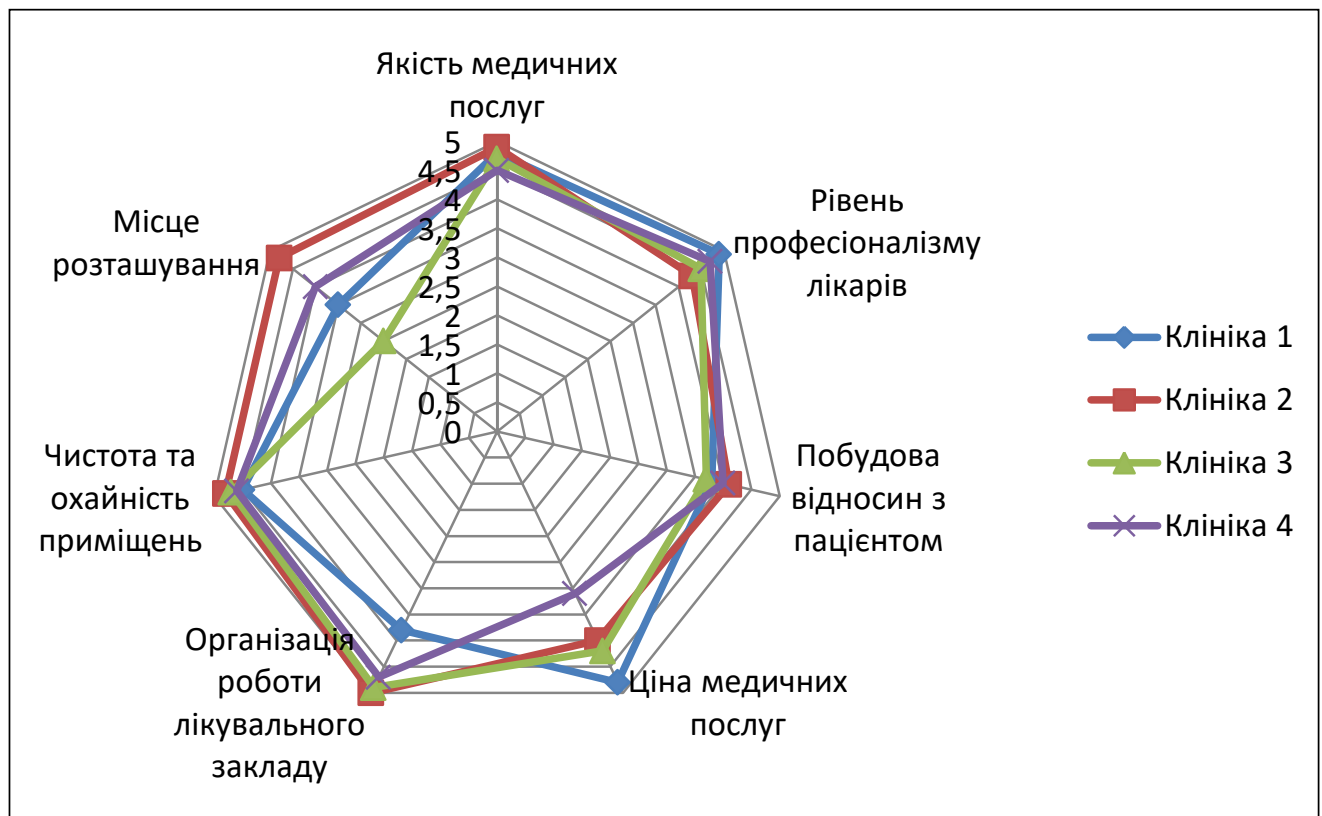

Рис. 1. Багатокутник конкурентоспроможності медичних закладів 
Результати ранжування медичних закладів

\begin{tabular}{|c|c|c|c|c|c|c|c|c|c|}
\hline \multirow[b]{2}{*}{ 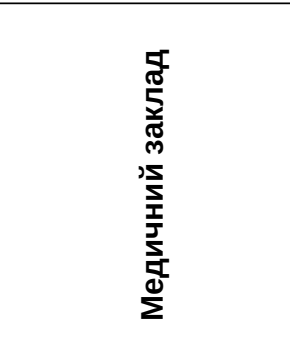 } & \multicolumn{7}{|c|}{ Показники і ранги } & \multirow[b]{2}{*}{ 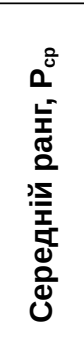 } & \multirow[b]{2}{*}{ 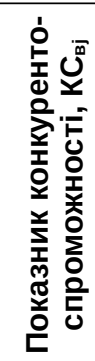 } \\
\hline & 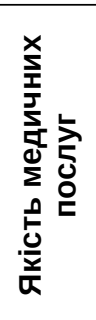 & 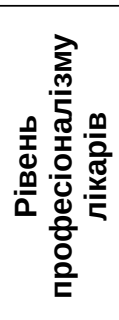 & 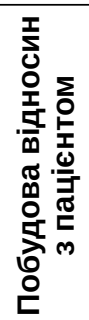 & 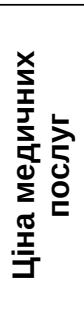 & 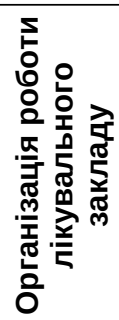 & 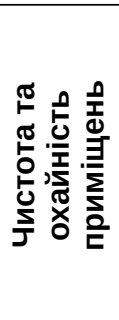 & 竞皇 & & \\
\hline Клініка 1 & 2 & 1 & 3 & 1 & 4 & 4 & 3 & 2,15 & 0.410 \\
\hline Клініка 2 & 1 & 4 & 1 & 3 & 1 & 1 & 1 & 2,00 & 0.487 \\
\hline Клініка 3 & 3 & 3 & 4 & 2 & 2 & 2 & 4 & 2,90 & 0.026 \\
\hline Клініка 4 & 4 & 2 & 2 & 4 & 3 & 3 & 2 & 2,95 & 0.000 \\
\hline Значення ознаки, $\alpha_{i}$ & 0,20 & 0,20 & 0,15 & 0,20 & 0,10 & 0,05 & 0,10 & - & - \\
\hline
\end{tabular}

конкурентних переваг, оптимізації асортименту медичних послуг тощо.

Висновки 3 проведеного дослідження. У результаті проведеного дослідження оцінено конкурентоспроможність медичних закладів із використанням методики проф. Г.П. Іспіряна на основі даних, отриманих експертним методом. Експерти вибрали найвагоміші показники та оцінювали їх для чотирьох приватних клінік за 5-бальною шкалою. Медичні заклади було проранжовано і визначено середній ранг та показник конкурентоспроможності. На основі показника конкурентоспроможності визначено лідерів та аутсайдерів серед медичних закладів. Результати оцінки конкурентоспроможності можуть знайти використання у практичній діяльності медичних закладів.

\section{БІБЛІОГРАФІЧНИЙ СПИСОК:}

1. Бондаренко С.М. Ділова досконалість підприємств як фрактор конкурентоспроможності національної економіки України. Економічний простір, 2016. № 116. С. 200-208.

2. Бондаренко С.М., Леус А.Ю. Оцінка рівня якості продукції на підприємстві. Ефективна економіка. 2017. № 4. URL: http://www.economy.nayka.com.ua/ ?op=1\&z=5527 (дата звернення 05.11.2020).

3. Бондаренко С.М., Михайленко Н.В. Базова концепція загального управління якістю ТQМ: Роль персоналу. Економічний простір. 2015. № 103. С. 139-146.

4. Готь О.Я., Бондаренко С.М. Стратегія підприємства як чинник його конкурентоспроможності. Ефрективна економіка. 2017. № 6. URL: http://www.economy.nayka.com.ua/?op=1\&z=5660 (дата звернення 05.11.2020).

5. Испирян Г.П. Конкурентоспособность изделия и предприятия: поход и методика измерения. Сучасні технології в легкій та текстильній промисловості. 1995. № 2. C. 18-20.

6. Касич А.О., Харькова Ж.В. Управління конкурентними перевагами підприємства. Економічний аналіз. 2016. № 2. С. 79-85.
7. Літвінов О. Визначення фракторів конкурентоспроможності закладів охорони здоров'я в умовах інноваційного розвитку. Науковий вісник Одеського національного економічного університету. 2017. № 4. C. 58-69.

8. Мачуга Н.3. Лікарня як елемент фрормування ринку медичних послуг. Вісник Чернівецького торговельно-економічного інституту. Економічні науки. 2013. Вип. 2. С.226-230.

9. Портер М. Конкурентна стратегія. Техніки аналізу галузей і конкурентів. Київ : Наш фрормат, 2020. $424 \mathrm{c}$.

10.Шомникова А.В. Ринок медичних послуг: проблеми ефективного використання маркетингових досліджень. Наукові праці НДФІ. 2009. Вип. 2(47). С. 131-136.

\section{REFERENCES:}

1. Bondarenko S.M. (2016) Dilova doskonalistj pidpryjemstv jak faktor konkurentospromozhnosti nacionaljnoji ekonomiky Ukrajiny [Business excellence of enterprises as a factor of competitiveness of the national economy of Ukraine]. Ekonomichnyj prostir, no. 116, pp. 200-208.

2. Bondarenko S.M., Leus A.Ju. (2017) Ocinka rivnja jakosti produkciji na pidpryjemstvi [Assessment of the level of product quality at the enterprise]. Efektyvna ekonomika (electronic journal), no. 4. Available at: http://www.economy.nayka.com.ua/?op=1\&z=5527 (accessed 05 November 2020).

3. Bondarenko S.M., Mykhajlenko N.V. (2015) Bazova koncepciya zagalnogo upravlinnya yakistyu TQM: Rol personalu [Basic concept of total quality management TQM: The role of staff]. Ekonomichnyj prostir, no. 103, pp. 139-146.

4. Ghotj O.Ja., Bondarenko S.M. (2017) Strateghija pidpryjemstva jak chynnyk jogho konkurentospromozhnosti [Enterprise strategy as a factor of its competitiveness]. Efektyvna ekonomika (electronic journal), no. 6. Available at: http://www.economy.nayka.com.ua/ ?op=1\&z=5660 (accessed 05 November 2020).

5. Ispipyan G.P. (1995) Konkupentosposobnost' izdeliya i ppedppiyatiya: pokhod i metodika izmepeniya [Competitiveness of the product and the enterprise: 
the approach and measurement method]. Suchasni tekhnologiï v legkiy ta tekstil'niy ppomislovost, no. 2, pp. 18-20.

6. Kasych A.O., Khar'kova Zh.V. (2016) Upravlinnya konkurentnymy perevagamy pidpryyemstva [Management of competitive advantages of the enterprise] Ekonomichnyj analiz, no. 2, pp. 79-85.

7. Litvinov O. (2017) Vyznachennya faktoriv konkurentospromozhnosti zakladiv oxorony zdorov'ya v umovax innovacijnogo rozvytku [The value of the factors in the competitiveness of health protection in the minds of innovation development]. Naukovyj visnyk Odeskogo nacionalnogo ekonomichnogo universytetu, no. 4 , pp. 58-69.
8. Machuga N.Z. (2013) Likarnya yak element formuvannya rynku medychnyx poslug [Hospital as an element of forming the market of medical services]. Visnyk Cherniveczkogo torgovelno-ekonomichnogo instytutu. Ekonomichni nauky, vol. 2, pp. 226-230.

9. Porter M. (2020) Konkurentna strategiya. Texniky analizu galuzej i konkurentiv [Competitive strategy. Techniques of analysis of industries and competitors]. Kyiv: Nash format. (in Ukrainian)

10. Shomnykova A.V. (2009) Rynok medychnyx poslug: problemy efektyvnogo vykorystannya marketyngovyx doslidzhen [Medical services market: problems of effective use of marketing research]. Naukovi praci NDFI, vol. 2(47), pp. 131-136. 